\title{
Estimates of carbon turnover rates in the sea cucumber Apostichopus japonicus (Selenka) using stable isotope analysis: the role of metabolism and growth
}

\author{
Zhen-Long Sun ${ }^{1}$, Qin-Feng Gao ${ }^{1, *}$, Shuang-Lin Dong ${ }^{1}$, Paul K. S. Shin ${ }^{2}$, Fang Wang ${ }^{1}$ \\ ${ }^{1}$ Key Laboratory of Mariculture, Ministry of Education, Ocean University of China, 5 Yushan Road, Qingdao City, \\ Shandong Province 266003, PR China \\ ${ }^{2}$ Department of Biology and Chemistry and State Key Laboratory in Marine Pollution, City University of Hong Kong, \\ Tat Chee Avenue, Kowloon, Hong Kong SAR, China
}

\begin{abstract}
Stable isotope analysis is increasingly being used to determine the trophic relationships of aquatic ecosystems. Most ecological and biological conclusions from isotope analysis are based on the assumption that the tissues of the respective consumers are in equilibrium with the potential food sources. Such an assumption, however, is not always validated in individual field studies. Hence, knowledge of the stable isotope turnover rates for the experimental organisms is fundamental for interpreting isotopic data. In this study, the carbon isotopic turnover rates for body walls and intestines of sea cucumbers Apostichopus japonicus (Selenka) of different sizes were investigated. The carbon isotopic turnover rate for the intestine was found to be faster than that for the body wall. The carbon stable isotope turnover rate decreased with an increase in body size, owing to the decrease in the metabolic activities of the larger individuals. Metabolism, rather than growth, was the principal driver of carbon stable isotope turnover, contributing 80 to $90 \%$ of the turnover for the intestine and 60 to $75 \%$ for the body wall. Analysis of the relationship between carbon replacement and the metabolism of sea cucumbers showed that the half-lives of carbon isotope replacement for both intestine and body wall were significantly related to physiological activities in terms of the oxygen consumption rates and food ingestion rates of the sea cucumbers. Our findings suggested that differences in turnover rates between various species and tissues should be considered when using stable isotopes in ecological studies. It is proposed that further development of isotope mixing models is needed and that these models should integrate isotope turnover for specific species or tissues.
\end{abstract}

KEY WORDS: Sea cucumber - Apostichopus japonicus (Selenka) - Carbon turnover - Stable isotope $\cdot$ Metabolism

\section{INTRODUCTION}

Stable isotope analysis that provides a natural marker is used frequently in ecological studies to understand the energy flow and matter cycle along food chains and food webs (Peterson \& Fry 1987, Hobson 1999, McCutchan et al. 2003). Carbon sta- ble isotope ratios of organisms reflect the isotopic signatures of their diets with the correction of diettissue fractionation (trophic shift), which is generally consistent and well characterized (McCutchan et al. 2003, Logan et al. 2006, Tarboush et al. 2006). Thus, the carbon isotopic composition of a consumer and its prey items are related in a predictable pat- 
tern (Tieszen et al. 1983, Peterson \& Fry 1987, McCutchan et al. 2003). Carbon stable isotope, which typically discriminates with the delta value $(\delta)$ of $1 \%$ for each trophic level (Peterson \& Fry 1987), is often used to quantify food assimilation, providing the technical measure for analyzing consumers long-term food utilization (Peterson et al. 1985, Kurata et al. 2001, Yokoyama et al. 2005, Gao et al. 2006, Kharlamenko et al. 2008). These studies and their conclusions are based on the assumption that tissues of consumers are in isotopic equilibrium with their diet (Post 2002, Gao et al. 2006). However, this may not necessarily be true, since the carbon isotopic ratios of the food items absorbed by the consumer are always dynamic. This is due to the different mechanisms of carbon fixation between primary producers, the seasonality of food availability and the movement or migration of predators, as well as the difference in the physiological characteristics of various species (MacAvoy et al. 2006). When the carbon isotopic composition of the food shifts, the consumer may come to reflect the carbon isotopic signature of its new food. The speed with which the carbon isotopic composition of a consumer resembles that of its new diet depends mainly on the turnover rate of the carbon stable isotope in the consumer tissue (Tarboush et al. 2006). This turnover relies on both growth, i.e. the net addition of the newly developed part of the tissue, and metabolism, i.e. the replacement of the existing tissue by the newly assimilated substances (Hesslein et al. 1993, MacAvoy et al. 2005, 2006, Tarboush et al. 2006).

Because of the uncertainty of stable isotope analysis in field investigations, there is considerable demand for laboratory experiments under controlled conditions to determine the turnover rate of carbon stable isotope, especially for unstudied species (Fisk et al. 2009). To date, a number of such studies have been carried out for mammals (Tieszen et. 1983, MacAvoy et al. 2005, 2006), birds (Hobson \& Clark 1992), fishes (Hesslein et al. 1993, Harvey et al. 2002, Logan et al. 2006), amphibians (Reich et al. 2008, Fisk et al. 2009), and arthropods (Fry \& Arnold 1982, Frazer et al. 1997, Suring \& Wing 2009). Results of such studies indicated that the tissue carbon replacement varied among species. Generally, the carbon isotope turnover of endothermic organisms is much faster than that of ectothermic organisms, possibly due to the higher metabolic rates of endothermic species which result from them stabilizing their body temperature to optimize enzyme activities (MacAvoy et al. 2001). Furthermore, isotopic tissue replacement in endotherms, such as mammals and birds in which growth generally ceases at the adult stage, is predominantly attributable to metabolism (Tieszen et al. 1983, Hobson \& Clark 1992, MacAvoy et al. 2005, 2006). In contrast, isotopic change in ectotherms, especially the lifelong-growth species and juvenile individuals with marked growth and relatively lower metabolic rates, is explained by growth rather than metabolism (Hesslein et al. 1993, Logan et al. 2006, Weidel et al. 2010).

On the other hand, carbon isotopic turnover rates show obvious differences among various tissues for individuals. In general, more metabolically active tissues demonstrate faster turnover rates than those with lower metabolic activity. For example, Tieszen et al. (1983) compared the $\delta^{13} \mathrm{C}$ half-lives of various tissues of gerbils Meriones unguiculatus and revealed that the half-lives of different tissues increased in the sequence of liver $(6.4 \mathrm{~d})$, muscle (27.6 d) and brain (28.2 d). Hobson and Clark (1992) reported a similar trend for the half-life of carbon turnover for brown Japanese quails Coturnix japonica, where liver, blood, and muscle tissues exhibited increasing half-lives of 2.6, 11.4 and $12.4 \mathrm{~d}$, respectively. Despite numerous studies on carbon isotope turnover rate, experiments regarding the variations in carbon isotopic turnover among multiple tissues of ectothermic animals, including sea cucumbers, are scarce (Suring \& Wing 2009, Buchheister \& Latour 2010).

As an obligate deposit-feeding species (Liao 1980), the sea cucumber Apostichopus japonicus (Selenka) plays an important trophic role in marine ecosystems (Slater \& Carton 2009, Ren et al. 2010). The feeding activities of the species could effectively remove nutrient matter deposited in benthic habitats and consequently reduce the nutrient loadings in coastal ecosystems (Zheng et al. 2009). Thus, a number of stable isotope studies have been conducted to improve understanding of the feeding and ecology of sea cucumbers (Slater \& Carton 2010, Gao et al. 2011). Far less, however, is known about the processes of stable isotopes, such as isotopic fractionation and turnover, for this species. In the present study, 4 groups of sea cucumbers of different body size were examined to: (1) explore the shift in the process of carbon stable isotope turnover in the intestine and body wall of sea cucumbers by means of a controlled diet switch; (2) estimate the respective contribution of metabolism and growth to carbon isotope turnover for the intestine and body wall; and (3) compare the difference in carbon isotope turnover between various body sizes. 


\section{MATERIALS AND METHODS}

\section{Sea cucumbers}

Sea cucumbers of different sizes were collected from a commercial farm in Qingdao City, China. The smallest sea cucumbers in Group SA (see 'Materials and methods: Experiment' for group abbreviations) were collected from the seed hatchery workshop while the larger ones (Groups SB, SC and SD were collected from a culture pond by SCUBA diving (Sino-dive Diving Device Co.). Before farm collection, the sea cucumbers were fed a commercially formulated feed with a constant carbon isotopic composition for at least 12 mo to ensure that stable isotope turnover was complete and that the subsequent isotopic composition of all the sea cucumber individuals was the same.

\section{Diet preparation}

Previous studies have shown that the addition of a suitable proportion of muddy content in the sea cucumber feed is necessary to meet their nutritional requirements (Liu et al. 2009). The commercial feed used in the farm consisted of $60 \%$ macroalgae Laminaria sp. powder and $40 \%$ sea mud. For the dietswitch experiment in the laboratory, the formulated diet contained $80 \%$ red macroalgae Gracilaria bursapastori powder and $20 \%$ ashed $\left(550^{\circ} \mathrm{C}, 6 \mathrm{~h}\right)$ sea mud (grain size: $\sim 0.08 \mathrm{~mm}$ ). Prior to the start of the experiment, a preliminary analysis indicated that the carbon stable isotope of G. bursa-pastori, which was used as feed in the laboratory, was $-20.94 \pm 0.19 \%$, significantly different from that of the commercially produced sea cucumber feed $(-18.30 \pm 0.40 \%)$ used at the farm. The distinct isotopic values of the 2 feed types enabled us to identify the changes in the stable isotopic ratios of the sea cucumbers after the feed switch. Sea mud was collected from an intertidal zone in the sea cucumber farm, dried and ground to powder. It was then combusted to remove any organic material, avoiding possible changes in the stable isotope values of the food content due to contamination. The red algae and ashed sea mud powder were well mixed and pelletized for experimental use.

\section{Experiment}

The experiment was carried out at the Laboratory of the National Marine Science Research Centre
(LNMSRC), Qingdao, China and lasted 3 mo. The sea cucumbers collected from the farms were acclimated in the laboratory for $10 \mathrm{~d}$ at $17 \pm 0.5^{\circ} \mathrm{C}$ and a salinity of 33, which were the same as the conditions of the farm collection site. After acclimation, the sea cucumbers were divided into 4 (size, S) groups according to their wet body weight (mean $\pm \mathrm{SE}$ ): $\mathrm{SA}(5.14 \pm$ $0.17 \mathrm{~g}) ; \mathrm{SB}(15.30 \pm 0.43 \mathrm{~g}) ; \mathrm{SC}(36.44 \pm 0.88 \mathrm{~g}) ; \mathrm{SD}$ $(78.40 \pm 1.91 \mathrm{~g})$. Each group contained 54 sea cucumbers that were randomly allocated to 18 numbered glass aquaria $\left(50 \times 30 \times 40 \mathrm{~cm}^{3}, 45\right.$ l), i.e. 3 sea cucumber individuals were cultured in each aquarium. The average wet weights of the sea cucumbers were not statistically different between the aquaria within the respective group (ANOVA, $p>0.05$ ). Plexiglass barriers with holes were placed inside each aquarium to separate the 3 individuals to allow for individual growth measurement. The holes in the barriers and continuous aeration allowed enough water circulation to ensure homogenous conditions within each section of each aquarium.

During the experiment, 3 sea cucumbers in each aquarium and 3 aquaria for each group were sampled on Days 0, 7, 14, 28, 56, and 84. The aquaria were sampled in the sequence of the aquarium numbers to facilitate data recording. No sampling bias was possible since the sea cucumbers within each group were allocated to the aquaria randomly at the beginning of the experiment. The collected sea cucumbers were dissected, and the intestine and body wall were separated and immediately rinsed with distilled double deionised water. To minimize the variations in isotopic values between individuals, and to reduce the costs of stable isotope analysis, the body walls and intestines of the 3 individuals collected from the same aquarium were pooled as 1 replicate for analysis. Hence, triplicate animal tissues for each sampling were tested for isotopic values. Triplicate samples of the macroalgae Gracilaria bursa-pastori were also collected. All the samples for stable isotope analysis were stored at $-80^{\circ} \mathrm{C}$ freezer for future measurements.

Before dissection, the individual sea cucumbers were weighed to determine growth rate. Oxygen consumption rate $\left(V_{\mathrm{O} 2}, \mathrm{mg} \mathrm{h}^{-1}\right)$ was then measured according to Bao et al. (2010). Briefly, 6 randomly selected individuals from each group were placed separately in respiration chambers $(0.5$ to 1.51 depending on animal body size). The respiration chambers and 3 other empty chambers (control chambers) were placed in a large tank supplied with seawater at experiment-set temperatures to reduce the effects of temperature fluctuation on respiratory activities. 
After $2 \mathrm{~h}$, the dissolved oxygen (DO) levels of the experiment and control chambers were measured with a DO meter (YSI-5000).

During the experiment, sea cucumbers were fed with the prepared Gracilaria feed once every day at 17:00 $\mathrm{h}$. Uneaten feed residue was collected by siphon after $20 \mathrm{~h}$ and dried at $60^{\circ} \mathrm{C}$ for at least $72 \mathrm{~h}$, to a constant weight for further analysis. Half of the water in each aquarium was changed daily using sand-filtered seawater. The experimental temperature was $17 \pm 0.5^{\circ} \mathrm{C}$, salinity $\sim 30$ to 32 , DO at least $6.5 \mathrm{mg} \mathrm{l}^{-1}$ and photoperiod $14 \mathrm{~h}$ light:10 h dark.

No control group without diet switch was set up in the present experiment because the main objective of the study was to examine the contributions of growth and metabolism to the isotopic turnover of sea cucumbers of various sizes rather than the isotopic changes due to the diet switch. Previous studies have shown that no temporal changes were observed in control groups without diet change (MacAvoy et al. 2006, Fisk et al. 2009); moreover, the results of previous experiments were convincing even without a control group (Sakano et al. 2005, Logan et al. 2006, Buchheister \& Latour 2010, Nelson et al. 2011). In the present experiment, the sea cucumbers were cultured in a laboratory under conditions that were the same as those at the farm where the sea cucumbers were collected, and the conditions were kept constant throughout the experiment. Such constant conditions might avoid or minimize the effects of the experiment conditions on the physiology and a subsequent shift in the isotopic signature of the sea cucumbers.

\section{Measurement of carbon stable isotope}

The body walls and intestines of the sampled sea cucumbers were thawed and dried at $55^{\circ} \mathrm{C}$ for at least $72 \mathrm{~h}$ to a constant weight. Dried samples were ground to fine, homogeneous powder using a microgrinder and a sieve. The carbon stable isotope values were determined using an elemental analyzer coupled with an isotope ratio mass spectrometer (EAIRMS, ThermFinnigan MAT Delta-plus). The resulting isotope ratios were expressed in standard $\delta$-unit notation, defined as follows (Peterson \& Fry 1987):

$$
\delta^{13} \mathrm{C}=\left[\left(R_{\text {sample }} / R_{\text {standard }}\right)-1\right] \times 1000 \%
$$

where $R$ is the ratio of heavy and light isotopes in a sample, ${ }^{13} \mathrm{C} /{ }^{12} \mathrm{C}$. The values were reported relative to the Vienna Pee Dee Belemnite standard (PDB). A laboratory working-standard (glycine) was run for every 10 samples. Analytical precision was $\pm 0.1 \%$.

\section{Turnover model and data calculation}

The isotopic turnover model used in the present study was based on that of Hesslein et al. (1993), which predicts tissue isotopic signature as an exponential function including growth and metabolic components and is represented by

$$
C=C_{n}+\left(C_{0}-C_{n}\right) \times e^{-(k+m) \times t}
$$

where $C$ is the final isotopic signature of the sea cucumbers at the end of the experiment, $C_{n}$ is the expected isotopic signature of sea cucumbers in equilibrium with their new diet, $C_{0}$ is the initial isotope signature of sea cucumbers at the beginning of the experiment, $k$ is the growth rate constant, $m$ is the metabolic rate constant, and $t$ is experimental time in days. The growth rate constant $(k)$ was determined by monitoring the temporal changes in the mass of sea cucumber over experimental time and described as:

$$
k=\ln \left(M_{f} / M_{0}\right) / t
$$

(Buchheister \& Latour 2010), where $M_{f}$ is the mass of sea cucumber at the sampling time, $M_{0}$ is the initial mass at $t=$ Day 0 , and $t$ is time in days from the onset of the feeding experiment. Expected isotopic change due to growth alone was calculated using Eq. (1), where $m$ was set to 0 (Hesslein et al. 1993). Isotopic turnover due to metabolism was derived by comparing expected isotopic turnover due to growth to that which was experimentally observed. Any isotopic turnover in excess of that attributable to growth was metabolic tissue replacement, which was derived by fitting the exponential model to match the observed isotopic data using the software SPSS for Windows Release 16.0 (SPSS Inc. 2008). The best estimate of $m$ was the value that resulted in the least absolute sum of the differences between the calculated and observed isotopic values for each time interval (MacAvoy et al. 2005). Since the carbon turnover is attributable to $m$ and $k_{\text {, the relative }}$ contributions of $k$ or $m$ to carbon turnover were derived as the ratio of each parameter to the sum of the 2 parameters $(k+m)$ i.e. $k$ (or $m) /(k+m)$ (Buchheister \& Latour 2010).

In order to find the time (T) required for $\alpha \%$ turnover of carbon, the equation

$$
T=-\ln (1-\alpha / 100) /(k+m)
$$

is solved, where $\alpha$ is the percentage of turnover. To determine half-life (HL) of tissue carbon turnover, the equation is solved for $\alpha=50 \%$. The half-life value is reported in days. 
The oxygen consumption rate $\left(V_{\mathrm{O} 2}, \mathrm{mg} \mathrm{h}^{-1}\right)$ was calculated using the equations:

$$
V_{\mathrm{O} 2}=\left(\mathrm{DO}_{\mathrm{C}}-\mathrm{DO}_{\mathrm{E}}\right) \times V / t
$$

where $\mathrm{DO}_{\mathrm{C}}$ and $\mathrm{DO}_{\mathrm{E}}$ are the DO levels of the control and experimental chambers respectively, $V$ the volume of chamber and $t$ the experimental time. To eliminate the effect of the changes in body weight because of growth, $V_{\mathrm{O} 2}$ for each specific group of sea cucumber was size-standardized to the mean dry body weight using the following equation (Gao et al. 2008):

$$
Y_{\mathrm{S}}=\left(X_{\mathrm{S}} / X_{\mathrm{O}}\right)^{b} \times Y_{\mathrm{O}}
$$

where $Y$ and $X$ were oxygen consumption rate and sea cucumber dry weight, respectively, subscripts $S$ and $\mathrm{O}$ represent the standard and observed values respectively and $b$ is the power coefficient obtained from the allometric equations relating the oxygen consumption rate to the dry weight, i.e. $Y=a X^{b}$, where $a$ is the regression coefficient.

Since the relationships of body dry weight to the culture time follow the exponential model, the average body dry weight $\left(W_{\mathrm{A}}\right)$ from time $t_{1}$ to $t_{2}$ was calculated as:

$$
W_{\mathrm{A}}=\mathrm{e}^{(\ln W 1+\ln W 2) / 2}
$$

where $W 1$ and $W 2$ are the dry weights at time $t_{1}$ and $t_{2}$, respectively.

To compare the oxygen consumption rate per unit body weight (OCR, $\mathrm{mg} \mathrm{h}^{-1} \mathrm{~g}^{-1}$ ) between the sea cucumbers in different groups with various body sizes, the OCRs per unit body weight were calculated as follows:

$$
\mathrm{OCR}=Y_{\mathrm{S}} / W_{\mathrm{A}}
$$

Food ingestion rate per unit body weight (IR, $\mathrm{g} \mathrm{g}^{-1}$ $\mathrm{d}^{-1}$ ) was calculated following the equation:

$$
\mathrm{IR}=W_{\mathrm{F}} /\left(W_{\mathrm{A}} \times D\right)
$$

where $W_{\mathrm{F}}$ is the total mass (in $\mathrm{g}$ ) of the feed consumed by the sea cucumbers in the course of the entire experiment, and $D$ is the duration of the experiment (in d).

\section{Statistical analysis}

The difference in the isotopic ratios between intestine and body wall, paired by each sampling time for each specific group, and the contributions of growth and metabolism to the isotopic turnover for both intestine and body wall in all 4 groups were compared using paired Students $t$-tests. ANOVA with Tukey's HSD test for multiple comparisons was used to compare the carbon isotopic changes in the intestines and body walls of the sea cucumbers after the diet was changed, for the specific growth rate and the metabolic rate between the different groups, and the OCR and IR between the body sizes of the sea cucumber.

Regression analyses were applied using non-linear procedures to determine the relationships of $k, m$, and carbon isotope turnover rate to body size, OCR and IR, depending on the most appropriate function for each case. Prior to analysis, raw data were reviewed for normality of distribution and homogeneity of variance with the Kolmogorov-Smirnov test and Levene's test, respectively (Zar 2009). All statistical analyses were performed with software SPSS for Windows release 16.0 (SPSS 2008).

\section{RESULTS}

\section{Carbon isotopic shift}

The carbon isotope ratios of the intestines and body walls of the sea cucumbers for each sampling time are presented in Table 1 . The initial carbon isotope ratios of the intestines and body walls of the sea

\begin{tabular}{|c|c|c|c|c|c|c|c|c|}
\hline \multirow{2}{*}{$\begin{array}{l}\text { Time } \\
\text { (Day) }\end{array}$} & \multicolumn{4}{|c|}{ Intestine } & \multicolumn{4}{|c|}{-Bodv wall } \\
\hline & SA & SB & $\mathrm{SC}$ & $\mathrm{SD}$ & SA & SB & $\mathrm{SC}$ & $\mathrm{SD}$ \\
\hline 0 & $-17.32 \pm 0.07^{\mathrm{a}}$ & $-16.03 \pm 0.14^{\mathrm{a}}$ & $-15.93 \pm 0.10^{\mathrm{a}}$ & $-16.18 \pm 0.43^{\mathrm{ab}}$ & $-17.09 \pm 0.13^{\mathrm{a}}$ & $-15.68 \pm 0.32^{\mathrm{a}}$ & $-15.50 \pm 0.32^{\mathrm{a}}$ & $-15.65 \pm 0.06^{\mathrm{a}}$ \\
\hline 7 & $-18.40 \pm 0.55^{b c}$ & $-17.03 \pm 0.04^{b}$ & $-16.45 \pm 0.07^{b}$ & $-16.47 \pm 0.04^{\mathrm{bc}}$ & $-17.48 \pm 0.34^{\mathrm{b}}$ & $-16.00 \pm 0.23^{a}$ & $-15.69 \pm 0.04^{\mathrm{a}}$ & $-15.67 \pm 0.06^{\mathrm{a}}$ \\
\hline 14 & $-18.88 \pm 0.19^{\mathrm{cd}}$ & $-17.63 \pm 0.26^{c}$ & $-16.98 \pm 0.14^{\mathrm{c}}$ & $-16.89 \pm 0.40^{\mathrm{c}}$ & $-17.92 \pm 0.07^{\mathrm{c}}$ & $-16.35 \pm 0.09^{b}$ & $-16.05 \pm 0.07^{b}$ & $-15.98 \pm 0.04^{b}$ \\
\hline 28 & $-19.20 \pm 0.26^{\mathrm{d}}$ & $-18.25 \pm 0.25^{\mathrm{d}}$ & $-17.67 \pm 0.08^{\mathrm{d}}$ & $-17.49 \pm 0.07^{\mathrm{d}}$ & $-18.56 \pm 0.12^{\mathrm{d}}$ & $-16.92 \pm 0.07^{c}$ & $-16.45 \pm 0.12^{\mathrm{c}}$ & $-16.32 \pm 0.09^{c}$ \\
\hline 56 & $-20.15 \pm 0.15^{\mathrm{e}}$ & $-18.88 \pm 0.40^{\mathrm{e}}$ & $-18.39 \pm 0.03^{\mathrm{e}}$ & $-18.01 \pm 0.08^{\mathrm{e}}$ & $-19.51 \pm 0.53^{\mathrm{e}}$ & $-17.81 \pm 0.12^{\mathrm{d}}$ & $-17.52 \pm 0.13^{\mathrm{d}}$ & $-16.94 \pm 0.07^{\mathrm{d}}$ \\
\hline 84 & $-20.04 \pm 0.42^{\mathrm{e}}$ & $-19.64 \pm 0.12^{f}$ & $-19.11 \pm 0.18^{\mathrm{f}}$ & $-18.70 \pm 0.21^{\mathrm{f}}$ & $-19.78 \pm 0.20^{\mathrm{e}}$ & $-19.78 \pm 0.24^{\mathrm{e}}$ & $-17.91 \pm 0.12^{\mathrm{e}}$ & $-17.39 \pm 0.04^{\mathrm{e}}$ \\
\hline
\end{tabular}

Table 1. Apostichopus japonicas (Selenka). Carbon stable isotope ratios of intestines and body walls of sea cucumbers in different groups. Time is in days from start of experiment. Samples were grouped according to wet weight into Groups SA (5.14 $\pm 0.17 \mathrm{~g})$, SB $(15.30 \pm 0.43 \mathrm{~g}), \mathrm{SC}(36.44 \pm 0.88 \mathrm{~g})$, and SD $(78.40 \pm 1.91 \mathrm{~g})$. Data are presented as mean \pm 1 SE. Different superscripted letters within the same column show significant difference at $p<0.05$ 
cucumbers in Group SA were different from those in Groups SB, SC, and SD due to the different food conditions (between the seed hatchery workshop where the sea cucumbers in Group SA were collected and the culture pond where the sea cucumbers in Groups $\mathrm{SB}, \mathrm{SC}$ and SD were collected). After the feed switch in the laboratory, isotope ratios of both intestines and body walls of the sea cucumbers for the 4 groups gradually decreased during the $84 \mathrm{~d}$ experiment owing to the assimilation of the isotopically lighter feed in the laboratory. The carbon isotope ratios of intestines were significantly lower than those of body walls (paired Students $t$-test, $\mathrm{p}<0.05$ ). For the intestines, significant shifts in the carbon isotopic values relative to the initial values before the diet switch, were observed on Day 7 (after the feed switch) for all groups except Group SD. For the body walls, significant changes in the carbon isotope values on Day 7 only occurred in the smallest sea cucumbers in Group SA, while the obvious changes in the isotope ratios of body walls for the larger sea cucumbers in Groups SB, SC, and SD commenced from Day 14.

\section{Growth, metabolism and isotopic turnover}

The growth, metabolism, and the isotopic turnover of the intestines and body walls of the sea cucumbers for the 4 groups are summarized in Table 2. The specific growth rates $(k)$ were significantly different between groups (ANONA, p $<0.001$ ). The $k$ values were negatively related to the average body weight for each group $\left(r^{2}=0.96, p<0.05\right)$, with the highest value of $0.0111 \pm 0.0004 \mathrm{~d}^{-1}$ for Group SA and the lowest value of $0.0016 \pm 0.0001 \mathrm{~d}^{-1}$ for Group SD. The contributions of metabolism to the isotopic turnover, represented by $m$ for both intestines and body walls in all 4 groups, were significantly higher than the corresponding contributions of growth, represented by the $k$ values (paired Student's $t$-test, $\mathrm{p}<0.05$ ). In addition, significant differences in the values of $m$ were found between the 2 tissue types, i.e. intestine and body wall, and between the 4 groups (ANOVA, p $<0.05$ ). The values of $m$ for intestines were higher than those for body walls, and $m$ values were negatively related to the sizes of sea cucumbers (for the intestine: $r^{2}=0.96, p<0.05$; for the body wall: $r^{2}=$ $0.86, \mathrm{p}<0.05)$. The turnover rates driven by both growth and metabolism in terms of $k+m$ showed a trend similar to the $m$ values. The turnover rates of the intestines were significantly higher than those of the body walls and were negatively related to the sizes of the sea cucumbers (for the intestine, $r^{2}=0.95$, $\mathrm{p}<0.05$; for the body wall, $\left.\mathrm{r}^{2}=0.91, \mathrm{p}<0.05\right)$. The ratios of metabolism to the sum of growth and metabolism suggested that metabolic tissue replacement accounted for 80 to $90 \%$ and 60 to $75 \%$, respectively, depending on the sizes of the sea cucumbers, and the carbon isotopic turnover for the intestine and body wall. The differences in growth and metabolism between the different groups resulted in different time courses for the shifts in isotopic values for both intestines (Fig. 1) and body walls (Fig. 2). The smaller sea cucumbers responded more quickly to the diet switch than the larger ones. Accordingly, for intestines or body walls, the isotopic ratios of the smaller sea cucumbers were closer to the isotopic ratios of the diet relative to the larger sea cucumbers at the end of the experiment. Because of the significant difference in turnover rate, the half-life of carbon turnover in the intestines was lower than that of the body walls. In addition, the half-lives of carbon turnover of intestines and body walls were positively related to body size (for the intestine, $\mathrm{r}^{2}=0.98, \mathrm{p}<0.05$; for the body wall, $\left.\mathrm{r}^{2}=0.96, \mathrm{p}<0.05\right)$.

Table 2. Apostichopus japonicas (Selenka). Initial and final carbon isotope ratios $\left(\delta^{13} \mathrm{C}\right)$, specific growth rate constant $(k)$, metabolic rate constant $(m)$, isotopic turnover rate $(k+m)$ and half-lives of intestines and body walls of sea cucumbers in different groups (for an explanation of body size groups see Table 1). Data are presented as mean $\pm 1 \mathrm{SE}$

\begin{tabular}{|c|c|c|c|c|c|c|c|}
\hline \multirow[t]{2}{*}{ Tissue } & \multirow{2}{*}{$\begin{array}{l}\text { Body } \\
\text { size }\end{array}$} & \multicolumn{2}{|c|}{$-\delta^{13} \mathrm{C}(\%)-$} & \multirow{2}{*}{$k\left(\mathrm{~d}^{-1}\right)$} & \multirow[t]{2}{*}{$m\left(\mathrm{~d}^{-1}\right)$} & \multirow[t]{2}{*}{$k+m\left(\mathrm{~d}^{-1}\right)$} & \multirow{2}{*}{$\begin{array}{l}\text { Half-life } \\
\text { (d) }\end{array}$} \\
\hline & & Initial & Final & & & & \\
\hline \multirow[t]{4}{*}{ Intestine } & SA & $-17.32 \pm 0.07$ & $-20.04 \pm 0.24$ & $0.0111 \pm 0.0004$ & $0.0508 \pm 0.0171$ & $0.0619 \pm 0.0171$ & 11.22 \\
\hline & SB & $-16.03 \pm 0.08$ & $-19.64 \pm 0.07$ & $0.0050 \pm 0.0003$ & $0.0245 \pm 0.0110$ & $0.0295 \pm 0.0110$ & 23.50 \\
\hline & $\mathrm{SC}$ & $-15.93 \pm 0.06$ & $-19.11 \pm 0.10$ & $0.0027 \pm 0.0005$ & $0.0160 \pm 0.0012$ & $0.0187 \pm 0.0046$ & 37.07 \\
\hline & $\mathrm{SD}$ & $-16.18 \pm 0.25$ & $-18.70 \pm 0.12$ & $0.0016 \pm 0.0001$ & $0.0113 \pm 0.0046$ & $0.0129 \pm 0.0047$ & 53.73 \\
\hline \multirow[t]{4}{*}{ Body wall } & SA & $-17.09 \pm 0.08$ & $-19.78 \pm 0.14$ & $0.0111 \pm 0.0004$ & $0.0213 \pm 0.0171$ & $0.0324 \pm 0.0114$ & 21.39 \\
\hline & SB & $-15.68 \pm 0.19$ & $-19.78 \pm 0.07$ & $0.0050 \pm 0.0003$ & $0.0078 \pm 0.0110$ & $0.0128 \pm 0.0024$ & 54.15 \\
\hline & $\mathrm{SC}$ & $-15.50 \pm 0.19$ & $-17.91 \pm 0.07$ & $0.0027 \pm 0.0005$ & $0.0079 \pm 0.0012$ & $0.0106 \pm 0.0033$ & 65.39 \\
\hline & SD & $-15.65 \pm 0.03$ & $-17.39 \pm 0.02$ & $0.0016 \pm 0.0001$ & $0.0050 \pm 0.0046$ & $0.0066 \pm 0.0060$ & 105.02 \\
\hline
\end{tabular}




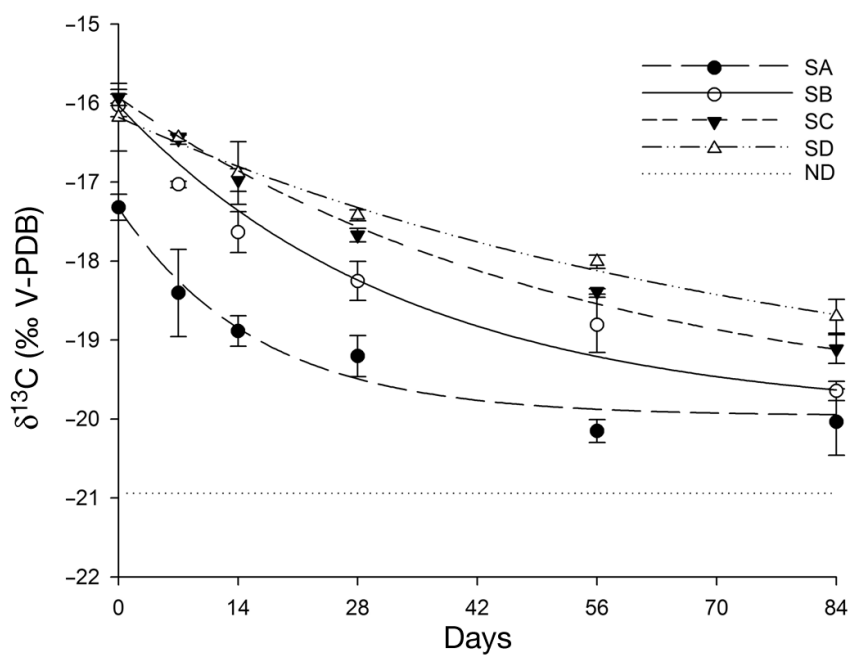

Fig. 1. Apostichopus japonicas (Selenka). Temporal changes in the observed $\delta^{13} \mathrm{C}$ values of intestines of the sea cucumbers in different groups. Error bars are \pm 1 SE. Samples were grouped according to wet weight into Groups SA (5.14 \pm $0.17 \mathrm{~g}), \mathrm{SB}(15.30 \pm 0.43 \mathrm{~g}), \mathrm{SC}(36.44 \pm 0.88 \mathrm{~g})$, and SD $(78.40 \pm 1.91 \mathrm{~g})$. ND: new diet; V-PDB: Vienna Pee Dee Belemnite standard

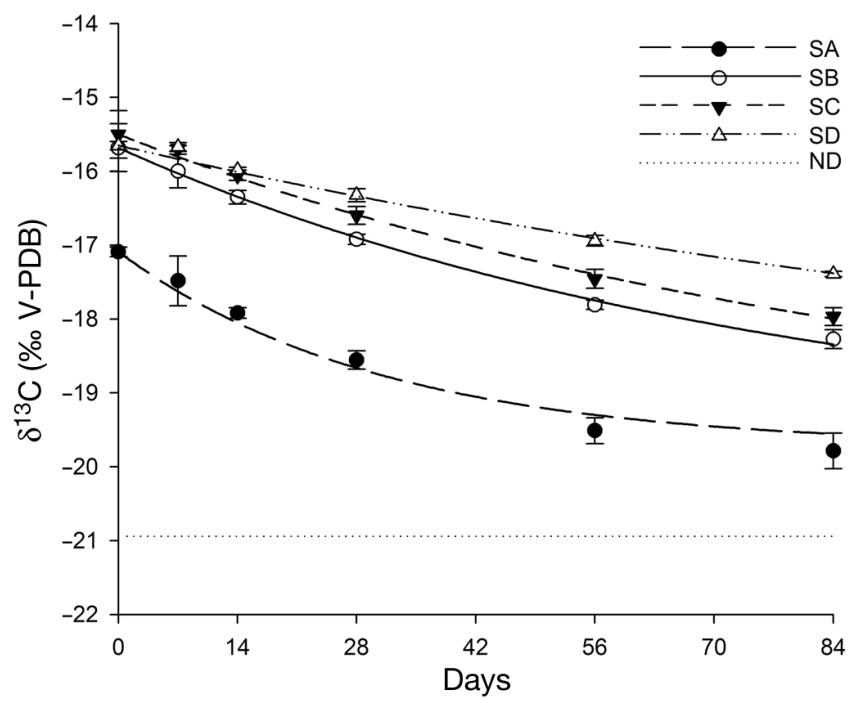

Fig. 2. Apostichopus japonicas (Selenka). Temporal changes in the observed $\delta^{13} \mathrm{C}$ values of body walls of the sea cucumbers in different groups. Error bars are $\pm 1 \mathrm{SE}$. For explanation of Groups SA-SD see Fig. 1. ND: new diet; V-PDB: Vienna Pee Dee Belemnite standard

As shown in Table 3, OCR and IR were significantly different between body sizes of the sea cucumbers (ANOVA, $\mathrm{p}<0.05$ ). The half-lives of carbon isotope turnover for both intestine and body wall related negatively to OCR (Fig. 3) and IR (Fig. 4), according to logarithmic models. The fitted equations that described the relationships between half-lives and OCR for intestine and body wall are:
Table 3. Apostichopus japonicas (Selenka). The oxygen consumption rate per unit body weight $\left(\mathrm{OCR}, \mathrm{mg} \mathrm{g}^{-1} \mathrm{~h}^{-1}\right)$ and ingestion rate per unit body weight (IR, $\mathrm{g} \mathrm{g}^{-1} \mathrm{~d}^{-1}$ ). The data were presented as mean $\pm 1 \mathrm{SE}$. For an explanation of body size groups see Table 1. Different superscripted letters within the same row mean significant difference at $p<0.05$

\begin{tabular}{|lcc|}
\hline Body size & OCR $\left(\mathrm{mg} \mathrm{g}^{-1} \mathrm{~h}^{-1}\right)$ & $\mathrm{IR}\left(\mathrm{g} \mathrm{g}^{-1} \mathrm{~d}^{-1}\right)$ \\
\hline SA & $0.46 \pm 0.06^{\mathrm{a}}$ & $0.24 \pm 0.02^{\mathrm{a}}$ \\
SB & $0.28 \pm 0.04^{\mathrm{b}}$ & $0.19 \pm 0.02^{\mathrm{b}}$ \\
SC & $0.21 \pm 0.03^{\mathrm{bc}}$ & $0.09 \pm 0.00^{\mathrm{c}}$ \\
SD & $0.16 \pm 0.03^{\mathrm{c}}$ & $0.05 \pm 0.00^{\mathrm{d}}$ \\
\hline
\end{tabular}

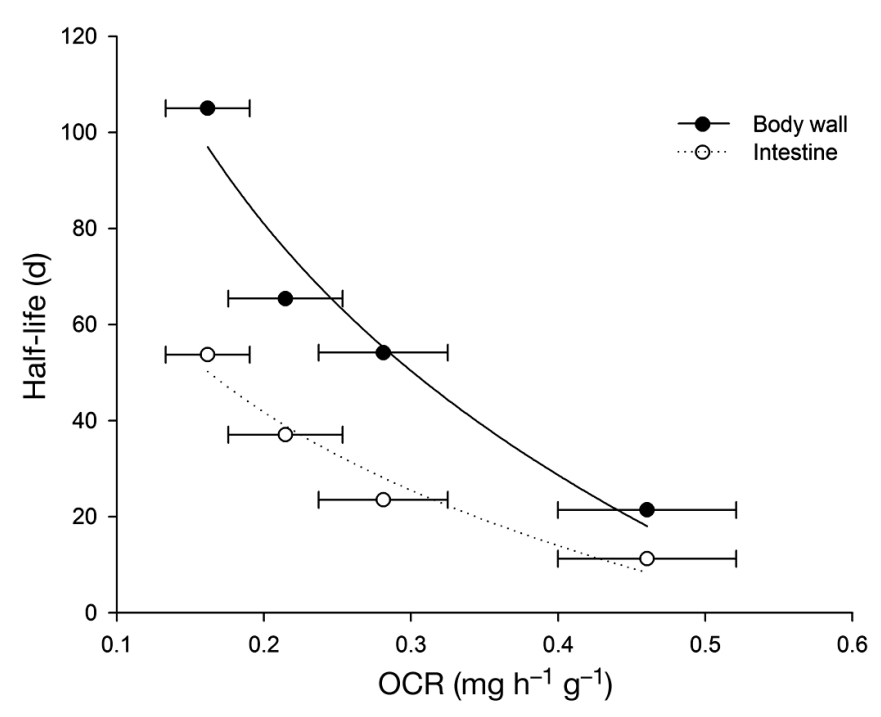

Fig. 3. Apostichopus japonicas (Selenka). Relationship of the half-lives of carbon isotopic turnover (d) to the oxygen consumption rate per unit body weight $\left(\mathrm{OCR}, \mathrm{mg} \mathrm{g}^{-1} \mathrm{~h}^{-1}\right)$ for intestines and body walls of sea cucumbers. Error bars are $\pm 1 \mathrm{SE}$

$\mathrm{HL}_{\text {intestine }}=-40.08 \ln (\mathrm{OCR})-22.78\left(\mathrm{r}^{2}=0.95, \mathrm{p}<0.05\right)$
$\mathrm{HL}_{\text {body wall }}=-75.52 \ln (\mathrm{OCR})-40.54\left(\mathrm{r}^{2}=0.95, \mathrm{p}<0.05\right)$

The fitted equations that described the relationships between half-lives and IR for intestine and body wall are:

$\mathrm{HL}_{\text {intestine }}=-26.69 \ln (\mathrm{IR})-24.88\left(\mathrm{r}^{2}=0.98, \mathrm{p}<0.05\right)$
$\mathrm{HL}_{\text {body wall }}=-48.55 \ln (\mathrm{IR})-40.86\left(\mathrm{r}^{2}=0.91, \mathrm{p}<0.05\right)$

For all groups of sea cucumbers in the present study, no sea cucumber completed the isotopic turnover after the $84 \mathrm{~d}$ experiment. According to the calculation based on Eq. (3), a period of 148.80, 312.21, 492.53 , and $713.98 \mathrm{~d}$ was expected to replace $99.99 \%$ of the carbon isotope in the intestines of the sea 


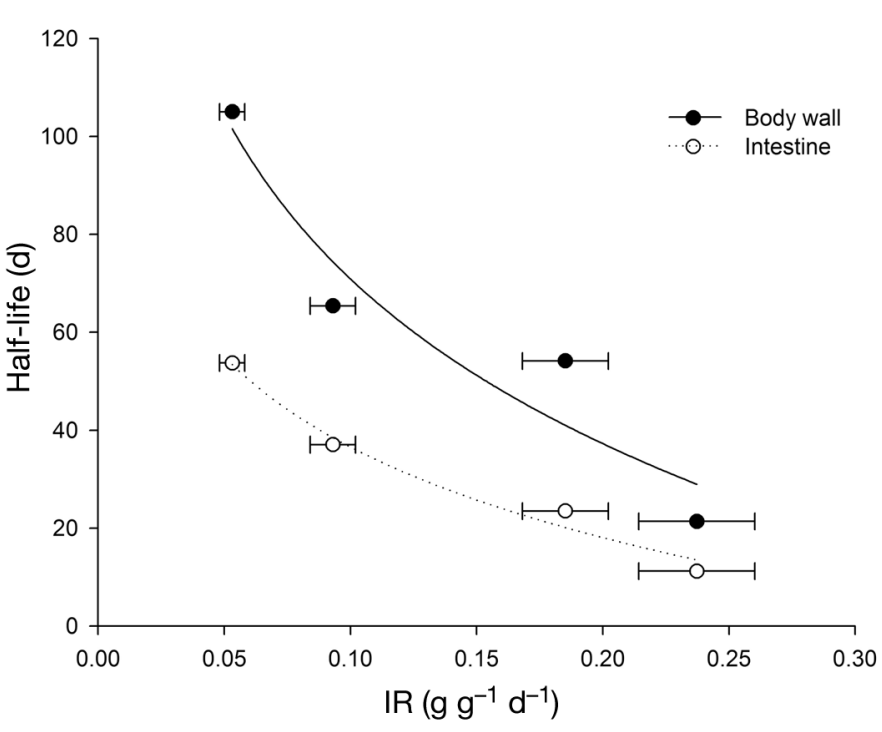

Fig. 4. Apostichopus japonicas (Selenka). Relationship of the half-lives of carbon isotopic turnover (d) to the ingestion rate per unit body weight (IR, $\mathrm{g} \mathrm{g}^{-1} \mathrm{~d}^{-1}$ ) for intestines and body walls of sea cucumbers. Error bars are $\pm 1 \mathrm{SE}$

cucumbers for Groups SA, SB, SC and SD, respectively. Periods of 284.27, 719.56, 868.90 and $1395.51 \mathrm{~d}$ were estimated for the body walls of the sea cucumbers in Groups SA, SB, SC and SD, respectively.

\section{DISCUSSION}

The enzyme systems of animals preferentially excrete the isotopically lighter ${ }^{12} \mathrm{C}$ in biochemical reactions during catabolic processes, resulting in the isotopic enrichment of ${ }^{13} \mathrm{C}$ in tissues, compared with their diets (DeNiro \& Epstein 1977, Peterson \& Fry 1987). When consumers were provided with a new diet with different $\delta^{13} \mathrm{C}$ values relative to those of their previous diet, the consumer tissue reflected the isotopic signature of the new diet. The present study examined carbon isotope turnover rates for the intestine and body wall of sea cucumbers in 4 groups following a laboratory diet switch. The results showed the significant differences in carbon isotopic turnover rates between tissue types and between body sizes. Metabolic tissue replacement accounted for 80 to $90 \%$ and 60 to $75 \%$ of carbon isotopic turnover for intestine and body wall, respectively, indicating that carbon isotope turnover was primarily dependent on metabolism rather than growth. The results also showed the significant relationships of the half-lives of carbon isotopic turnover to the metabolic activities of the sea cucumbers in terms of oxygen consumption and food ingestion.

\section{Tissue-specific isotope turnover}

Previous studies have shown that carbon isotopic turnover rates varied widely amongst tissues in endotherms (Tieszen et al. 1983, Hobson \& Clark 1992, MacAvoy et al. 2005, 2006). For example, MacAvoy et al. (2005) assessed the carbon isotopic turnover rates in the liver, muscle and blood of adult female inbred BALB/c mice, Mus musculus L., 1758, and found that the half-lives of carbon isotopic turnover of these tissues differed significantly. Few studies, however, have reported isotopic turnover variation amongst tissues in ectotherms. For a few species, such as summer flounder Paralichthys dentatus (Buchheister \& Latour 2010) and lobster Jasus edwardsii (Suring \& Wing 2009), the carbon isotopic turnover rate for blood was shown to be faster than that of muscle.

The results of the present study show that the turnover rate for intestines, as measured using $\delta^{13} \mathrm{C}$, was faster than that for body walls for all 4 groups. The carbon turnover half-life for intestines was almost half that for the body wall. This is consistent with the results reported by Tieszen et al. (1983) and Hobson \& Clark (1992), that the digestive organs, such as the liver, generally showed faster carbon turnover rates than other tissues, such as muscle, hair or bone collagen. Tieszen et al. (1983) also suggested that the carbon isotopic turnover rate was correlated strongly with the metabolic rate of the tissue involved. The faster turnover rate in the liver relative to the muscle might be attributable to the higher metabolic rate of liver compared to muscle (Thompson 1953, Evans-Ogden et al. 2004, Arneson \& MacAvoy 2005, Buchheister \& Latour 2010).

Another factor influencing the carbon isotopic fractionation is the variations in the lipid contents for different tissues. The tissues containing higher proportions of lipids showed more negative carbon isotopic ratios than those with lower lipid contents, owing to the discrimination against ${ }^{13} \mathrm{C}$ during the processes of lipid synthesis (DeNiro \& Epstein 1977, Tieszen et al.1983). On the other hand, lipid functions as a storage substance for energy and matter metabolism, and tissues with high lipid content accordingly appear to have faster turnover than those with lower lipid content (Nelson et al. 2011). Lipid content in the intestines of sea cucumbers is obviously higher than that in the body walls (Xiang et al. 2006). As a result, in the present study, the body wall showed a higher carbon isotope ratio (Table 1) and a longer half-life of isotope turnover (Table 2) relative to the intestine. 


\section{Body-size-specific isotope turnover}

Results of the present study showed that carbon isotope for both intestines and body walls of sea cucumbers with larger body sizes turned over more slowly than those with smaller body sizes. The halflives of tissue isotopic replacement were 11.22 to $21.39 \mathrm{~d}$ for the sea cucumbers in Group SA versus 53.73 to 105.02 d for those in Group SD (Table 2). This was consistent with other findings that indicated that the larger the body size of the animals, the more slowly the carbon turnover rate of tissues occurred. In an in situ experiment with whole-lake ${ }^{13} \mathrm{C}$ addition, for example, the half-life of isotopic turnover for dorsal muscles was 8 to $18 \mathrm{~d}$ in Age 0 fish and 116 to $173 \mathrm{~d}$ in Age 5 to 6 fish, depending on the species (Weidel et al. 2010). MacAvoy et al. (2006) reviewed various studies that examined birds with body masses ranging from $11.5 \mathrm{~g}$ to $1250 \mathrm{~g}$ and metabolic rates in terms of oxygen consumption ranging from 0.014 to $0.049 \mathrm{ml} \mathrm{O}_{2} \mathrm{~g}^{-1} \mathrm{~min}^{-1}$ and concluded that the carbon turnover half-lives of blood for birds showed a negative logarithmic relationship to metabolic rate. They thus showed that it is possible to establish the relationship between isotopic turnover and a common parameter such as metabolic rate, hence improving understanding of the ways in which isotopic turnover can be applied. Prior to the study by MacAvoy et al. (2006), researchers using stable isotopes to characterize food webs had to evaluate the minimum period that the organisms require to reach the status of isotopic equilibrium (Tieszen et al. 1983, MacAvoy et al. 2006).

The relationships of the carbon turnover rates to the metabolic levels in terms of OCR and IR revealed that higher metabolic activities of organisms resulted in more rapid carbon turnover and vice versa. During the metabolic processes, animals consume oxygen to break up the storage substances for energy generation in order to maintain their physiological activities. Thus, in hydrobiological studies, the oxygen consumption rate is considered to be a cumulative index of metabolic losses during aerobic metabolism, and is thought to be the most informative characteristic of metabolism (Galkovskaya 1995). On the other hand, ingestion rate is also metabolically characteristic since anabolic metabolism prefers to produce macromolecules such as carbohydrates, proteins or lipids utilizing nutrients from recently ingested diets for somatic growth and metabolic activities. In the present experiment, the measured OCR and IR, as well as the relationships of OCR and IR to body sizes were in accordance with the observations of other re- searchers (Yang et al. 2006, Liu et al. 2009, Bao et al. 2010). The OCR and IR were highly correlated with the half-lives of carbon turnover, a finding consistent with that found for birds (MacAvoy et al. 2006).

\section{Contribution of growth and metabolism to isotopic turnover}

The tissue components of organisms are dynamically equilibrated, i.e. there is continuous synthesis of new components and degradation of older ones and the subsequent tissue replacement. Both catabolic breakdown and anabolic incorporation of tissue components, i.e. proteins, lipids, carbohydrates contribute to the tissue turnover. During the growth periods, the balance between breakdown and replacement is disturbed and the new tissue synthesis exceeds catabolic breakdown, resulting in a net increase in the biomass of the organisms. Hence, the tissue isotopic turnover rate depends on both growth and metabolism (MacAvoy et al. 2005).

In the present experiment, the fitted exponential Hesslein model (Hesslein et al. 1993) closely matched the observed isotopic data, indicating that this timebased model was applicable for laboratory experiments in which the environmental conditions, such as temperature and food sources were controlled (Buchheister \& Latour 2010). The turnover rates due to metabolic tissue replacement were obviously higher than those predicted by growth alone, which demonstrated that, for the sea cucumber, metabolism predominantly contributed to the total tissue carbon isotopic turnover, despite the fact that the tissue replacement was derived from both somatic growth and metabolic tissue replacement (Tarboush et al. 2006). In fact, the results of the present study suggest that metabolic tissue replacement accounted for 80 to $90 \%$ and 60 to $75 \%$ of carbon isotopic turnover for intestines and body walls, respectively. These estimations of the contributing proportion of metabolism to total carbon isotope turnover were consistent with Tarboush et al. (2006), who found that the tissue replacement due to metabolism in a juvenile zebra fish Danio rerio (Hamilton, 1822) accounted for about $74 \%$ of carbon isotopic turnover for muscle. However, the high contributions of metabolism to the carbon isotopic turnover of the sea cucumber in the present study were in contrast to observations for other ectothermic animals, such as brown shrimp juveniles (Fry \& Arnold 1982), red drum larvae (Herzka \& Holt 2000), and broad whitefish (Hesslein et al. 1993), where isotopic turnover primarily depended on 
growth. The findings of these latter 3 studies combined with our own results suggest that there is a difference in the bioenergetic allocations for metabolism and growth between slow-growing ectotherms, such as sea cucumber, and fast-growing endotherms, such as larval or juvenile fish. More energy was allocated to the metabolic activities relative to growth for slowgrowing organisms and vice versa for fast-growing organisms. Previous studies on the energy budget of the sea cucumber indicated that the energy deposit in growth accounted for 5 to $10 \%$ of total energy taken up by the sea cucumber (Yuan et al. 2007, Liu et al. 2009), which was consistent with the results of the current study, i.e. the contribution of growth to carbon isotopic turnover was far less than that of metabolism.

The low energy allocation for growth reflects the adaptive strategy of the sea cucumber in response to the poor food conditions in the field. The sea cucumber is a typical deposit-feeding species and mainly feeds on sediment containing decayed macroalgae, pelagic and benthic microalgae (Liao 1980, Zhang et al. 1995). In response to the poor food quality and quantity in benthic conditions, the sea cucumber shows active regulation of energy allocation. As a result, more energy is utilized for maintaining metabolic activities. Additionally, the sea cucumber has no specialized digestive organs for grinding or glands for chemical digestion, and digestive enzyme activity in the gut is very low (Yingst 1976, Massin 1982, Cui et al. 2000). These factors lead to low digestive efficiency and high energy loss during the metabolic processes, and low energy allocation for growth (Yuan et al. 2007, Liu et al. 2009).

Isotopic signatures are widely used in ecological studies of trophic relationships to indicate the food sources of predators. Stable isotope techniques can be applied in both qualitative and quantitative ecological studies. Under natural conditions, the prey items and isotopic signatures of the prey items are continuously changing (Franca et al. 2011, Visconti \& Manca 2011). Stable isotope analysis for the tissues of predators might reflect the 'average' food uptake by the consumers over a longer time scale, than is possible using gut content analysis, which reflects the short-term food uptake of the consumers (Hobson \& Welch 1992). Hence, one of the dominant applications of stable isotope analysis under natural conditions is to qualitatively track the tendency of longterm changes in the food webs rather than to quantify the food sources of the studied predators. It is difficult, sometimes impossible, to obtain the status of the isotopic equilibrium of predators in response to the dynamic changes in the isotopic signatures of the prey items (Faye et al. 2011, Visconti \& Manca 2011). However, complete stable isotope equilibrium is not a prerequisite for such qualitative studies.

For quantitative studies, however, it is essential to determine the isotopic turnover rate of the predator, i.e. the duration that the predator requires to reach isotopic equilibrium, in order to compute the food contributions of various prey items, using stable isotope mixing models proposed, for example, by Phillips \& Koch (2002) and Phillips \& Gregg (2003). This is especially true for those organisms with low isotopic turnover rates, such as the sea cucumber. In this case, a preliminary experiment in the laboratory with a diet switch is necessary to determine the halflife of the studied organism. Based on the determined half-life, for the investigations with human manipulation such as controlled diet switch (Yokoyama et al. 2002, Gao et al. 2006) or artificial isotope enrichment (Galvan et al. 2008), an adequate equilibrium period, longer than that required for the complete turnover of the isotope, should be provided. On the other hand, as mentioned above, stable isotope analysis is frequently used to track the temporal changes in food uptake by predators, and it is impossible to obtain isotope equilibrium because the isotopic signatures of the food sources are inconsistent and continuously dynamic under natural conditions. For such studies, if accurate quantifications of food sources, using isotope mixing models, are intended, it is proposed that the isotope half-life of the studied predator should be included as one of the coefficients in the models. For example, temporal changes in the food sources of consumers are frequently quantified using stable isotopes (Ben-David et al. 1997, Stenroth et al. 2006). If the isotopic turnover is too slow to result in an equilibrium period longer than that of the sampling interval (i.e. if stable isotope turnover or replacement is incomplete), problems will inevitably arise with respect to the application of the isotope models. In this case, we propose that the isotope mixing models should be further improved by integrating the relative ratio of sampling interval to the equilibrium period. It is expected that by including isotope turnover or equilibrium period in the isotope mixing models, the isotopic signature of the tissue part newly assimilated during the sampling interval might be mathematically separated from that of the entire tissue and the contributions of the potential food sources to the experimental consumers during the specific period would thus be quantified. Hence, further studies are needed to optimize the isotope mixing models and subsequently improve the precision of ecological results achieved from stable isotope analysis. 
Acknowledgements. This study was funded by grants from the National Natural Science Foundation of China (Project No. 31172426), the Ministry of Science and Technology of China (Project No. 2011BAD13B03), and the State Oceanic Administration of China (Project No. 200905020); it was supported by the Program for New Century Excellent Talents in University. We thank 3 anonymous reviewers for the constructive comments on the manuscript.

\section{LITERATURE CITED}

- Arneson LS, MacAvoy SE (2005) Carbon, nitrogen and sulfur diet-tissue discrimination in mouse tissues. Can J Zool 83:989-995

Bao J, Dong SL, Tian XL, Wang F, Gao QF, Dong YW (2010) Metabolic rates and biochemical compositions of Apostichopus japonicus (Selenka) tissue during periods of inactivity. Chin J Oceanol Limnol 28:218-223

Ben-David M, Flynn RW, Schell DM (1997) Annual and seasonal changes in diets of martens: evidence from stable isotope analysis. Oecologia 111:280-291

> Buchheister A, Latour RJ (2010) Turnover and fractionation of carbon and nitrogen stable isotopes in tissues of a migratory coastal predator, summer flounder (Paralichthys dentatus). Can J Fish Aquat Sci 67:445-461

Cui LB, Dong ZN, Lu YH (2000) Histological and histochemical studies on the digestive system of Apostichopus japonicus. Chin J Zool 35:2-4

DeNiro MJ, Epstein S (1977) Mechanism of carbon isotope fractionation associated with lipid synthesis. Science 197:261-263

- Evans-Ogden LJ, Hobson KA, Lank DB (2004) Blood isotopic $\left(\delta^{13} \mathrm{C}\right.$ and $\left.\delta^{15} \mathrm{~N}\right)$ turnover and diet-tissue fractionation factors in captive dunlin (Calidris alpine pacifica). Auk 121:170-177

Faye D, de Morais LT, Raffray J, Sadio O, Thiaw OT, Le Loc'h F (2011) Structure and seasonal variability of fish food webs in an estuarine tropical marine protected area (Senegal): evidence from stable isotope analysis. Estuar Coast Shelf Sci 92:607-617

Fisk AT, Sash K, Jaerz J, Palmer W, Carroll JP, MacNeil MA (2009) Metabolic turnover rates of carbon and nitrogen stable isotopes in captive juvenile snakes. Rapid Commun Mass Spectrom 23:319-326

> França S, Vasconcelos RP, Tanner S, Máguas C, Costa MJ, Cabral HN (2011) Assessing food web dynamics and relative importance of organic matter sources for fish speices in two Portuguese estuaries: a stable isotope approach. Mar Environ Res 72:204-215

> Frazer TK, Ross RM, Quetin LB, Montoya JP (1997) Turnover of carbon and nitrogen during growth of larval krill, Euphausia superba Dana: a stable isotope approach. J Exp Mar Biol Ecol 212:259-275

> Fry B, Arnold C (1982) Rapid ${ }^{13} \mathrm{C} /{ }^{12} \mathrm{C}$ turnover during growth of brown shrimp (Penaeus aztecus). Oecologia 54:200-204

> Galkovskaya GA (1995) Oxygen consumption rate in rotifers. Hydrobiologia 313-314:147-156

> Galvan K, Fleeger JW, Fry B (2008) Stable isotope addition reveals dietary importance of phytoplankton and microphytobenthos to saltmarsh infauna. Mar Ecol Prog Ser 359:37-49

> Gao QF, Shin PKS, Lin GH, Chen SP, Cheung SG (2006) Stable isotope and fatty acid evidence for uptake of organic waste by green-lipped mussels Perna viridis in a polyculture fish farm system. Mar Ecol Prog Ser 317:273-283

Gao QF, Xu WZ, Liu XS, Cheung SG, Shin PKS (2008) Seasonal changes in $\mathrm{C}, \mathrm{N}$ and $\mathrm{P}$ budgets of green-lipped mussels Perna viridis and removal of nutrients from fish farming in Hong Kong. Mar Ecol Prog Ser 353:137-146

> Gao QF, Wang YS, Dong SL, Sun ZL, Wang F (2011) Absorption of different food sources by sea cucumber Apostichopus japonicus (Selenka) (Echinodermata: Holothuroidea): evidence from carbon stable isotope. Aquaculture 319:272-276

- Harvey CJ, Hanso PC, Essington TE, Brown PB, Kitchell JF (2002) Using bioenergetics models to predict stable isotope ratio in fishes. Can J Fish Aquat Sci 59:115-124

> Herzka SZ, Holt GJ (2000) Changes in isotopic composition of red drum (Sciaenops ocellatus) larvae in response to dietary shifts: potential applications to settlement studies. Can J Fish Aquat Sci 57:137-147

> Hesslein RH, Haallard KA, Ramlal P (1993) Replacement of sulfur, carbon and nitrogen in tissue of growing broad whitefish (Coregonus nasus) in response to a change in diet traced by $\delta^{34} \mathrm{~S}, \delta^{13} \mathrm{C}, \delta^{15} \mathrm{~N}$. Can J Fish Sci 50: 2071-2076

Hobson KA (1999) Tracing origins and migration of wildlife using stable isotopes: a review. Oecologia 120:314-326

Hobson KA, Clark RG (1992) Assessing avian diets using stable isotope I: turnover of ${ }^{13} \mathrm{C}$ in tissues. Condor 94 : 181-188

Hobson KA, Welch HE (1992) Determination of trophic relationships within a high Arctic marine food web using $\delta^{13} \mathrm{C}$ and $\delta^{15} \mathrm{~N}$ analysis. Mar Ecol Prog Ser 84:9-18

> Kharlamenko VI, Kiyashko SI, Rodkina SA, Imbs AB (2008) Determination of food sources of marine invertebrates from a subtidal sand community using analyses of fatty acids and stable isotopes. Russ J Mar Biol 34:101-109

Kurata K, Minami H, Kikuchi E (2001) Stable isotope analysis of food sources for salt marsh snails. Mar Ecol Prog Ser 223:167-177

Liao YL (1980) The aspidochirote holothurians of China with erection of a new genus in echinoderms: present and past. In: Jangoux M (ed) Echinoderms: present and past. Proceedings of the European Colloquium on Echinoderm. A. A. Balkema, Rotterdam, p 115-120

Liu Y, Dong SL, Tian XL, Wang F, Gao QF (2009) Effects of dietary sea mud and yellow soil on growth and energy budget of the sea cucumber Apostichopus japonicus (Selenka). Aquaculture 286:266-270

> Logan J, Haas H, Deegan L, Gaines E (2006) Turnover rates of nitrogen stable isotopes in the salt marsh mummichog, Fundulus heteroclitus, following a laboratory diet switch. Oecologia 147:391-395

MacAvoy SE, Macko SA, Garman GC (2001) Isotopic turnover in aquatic predators: quantifying the exploitation of migratory prey. Can J Aquat Sci 58:923-932

MacAvoy SE, Macko SA, Arneson LS (2005) Growth versus metabolic tissue replacement in mouse tissues determined by stable carbon and nitrogen isotope analysis. Can J Zool 83:631-641

MacAvoy SE, Arneson LS, Bassett E (2006) Correlation of metabolism with tissue carbon and nitrogen turnover rate in small mammals. Oecologia 150:190-201

Massin C (1982) Food and feeding mechanisms: Holothuroidea. In: Jangoux M, Lawrence JM (eds) Echinoderm nutrition. A.A. Balkema Publishers, Rotterdam, p 43-55 
McCutchan JH, Lewis WM, Kendall C, McGrath CC (2003) Variation in trophic shift for stable isotope ratios of carbon, nitrogen and sulfur. Oikos 102:378-390

Nelson J, Chanton J, Coleman F, Koenig C (2011) Patterns of stable carbon isotope turnover in gag, Mycteroperca microlepis, an economically important marine piscivore determined with a non-lethal surgical biopsy procedure. Environ Biol Fishes 90:243-252

Peterson BJ, Fry B (1987) Stable isotopes in ecosystem studies. Annu Rev Ecol Syst 18:293-320

Peterson BJ, Howarth RW, Garritt RH (1985) Multiple stable isotopes used to trace the flow of organic matter in estuarine food webs. Science 227:1361-1363

Phillips DL, Gregg JW (2003) Source partitioning using stable isotopes: coping with too many sources. Oecologia 136:261-269

Phillips DL, Koch PL (2002) Incorporating concentration dependence in stable mixing model. Oecologia 130: 114-125

> Post DM (2002) Using stable isotopes to estimate trophic position: models, methods, and assumptions. Ecology 83:703-718

Reich KJ, Bjorndal KA, Martínez del Rio C (2008) Effects of growth and tissue type on the kinetics of $\delta^{13} \mathrm{C}$ and $\delta^{15} \mathrm{~N}$ incorporation in a rapidly growing ectotherm. Oecologia 155:651-663

Ren YC, Dong SL, Wang F, Gao QF, Tian XL, Liu F (2010) Sedimentation and sediment characteristics in sea $\mathrm{cu}-$ cumber Apostichopus japonicus (Selenka) culture ponds. Aquacult Res 42:14-21

Sakano H, Fujiwara E, Nohara S, Ueda H (2005) Estimation of nitrogen stable isotope turnover rate of Oncorhynchus nerka. Environ Biol Fishes 72:13-18

Slater MJ, Carton AG (2009) Effect of sea cucumber (Australostichopus mollis) grazing on coastal sediments impacted by mussel farm deposition. Mar Pollut Bull 58: 1123-1129

Slater MJ, Carton AG (2010) Sea cucumber habitat differentiation and site retention as determined by intraspecific stable isotope variation. Aquacult Res 41:695-702

SPSS Inc (2008) SPSS 16.0 Student Version for Windows. Prentice Hall, Upper Saddle River, NJ

Stenroth P, Holmqvist N, Nystrom P, Berglund O, Larsson P, Graneli W (2006) Stable isotopes as an indicator in omnivorous crayfish (Pacifastacus leniusculus): the influence of tissue, sample treatment, and season. Can Bull Fish Aquat Sci 63:821-831

Suring E, Wing SR (2009) Isotopic turnover rate fractionation in multiple tissues of red rock lobster (Jasus edwardsii) and blue cod (Parapercis colias): consequences for ecological studies. J Exp Mar Biol Ecol 370:56-63

Editorial responsibility: James McClintock, Birmingham, Alabama, USA
Tarboush RA, MacAvoy SE, Macko SA, Connaughton V (2006) Contribution of catabolic tissue replacement to the turnover of stable isotopes in Danio rerio. Can J Zool 84:1453-1460

- Thompson RC (1953) Studies of metabolic turnover with tritium as a tracer. II. Gross studies on the rat. J Biol Chem 200:731-743

> Tieszen LL, Boutton TW, Tesdahl KG, Slade NA (1983) Fractionation and turnover of stable carbon isotopes in animal tissues: implications for $\delta^{13} \mathrm{C}$ analysis of diet. Oecologia 57:32-37

Visconti A, Manca M (2011) Seasonal changes in the $\delta^{13} \mathrm{C}$ and $\delta^{15} \mathrm{~N}$ signatures of the Lago Maggiore pelagic food web. J Limnol 70:263-271

Weidel BC, Carpenter RC, Kitchell JF, Zanden MJV (2010) Rates and components of carbon turnover in fish muscle: insights from bioenergetics models and a whole-lake ${ }^{13} \mathrm{C}$ addition. Can J Fish Aquat Sci 60:387-399

Xiang YH, Su XR, Dong MM (2006) The composition of amino acids and fatty acids in body walls and alimentary canals of sea cucumber Apostichopus japonicus. Fish Sci 25:280-283

> Yang HS, Zhou Y, Zhang T, Yuan XT, Li XX, Liu Y, Zhang FS (2006) Metabolic characteristics of sea cucumber Apostichopus japonicus (Selenka) during aestivation. J Exp Mar Biol Ecol 330:505-510

> Yingst JY (1976) The utilization of organic matter in shallow marine sediments by an epibenthic deposit-feeding holothurian. J Exp Mar Biol Ecol 23:55-69

> Yokoyama H, Higano J, Adachi K, Ishihi Y, Yamada Y, Pichitkul P (2002) Evaluation of shrimp polyculture system in Thailand based on stable carbon and nitrogen isotope ratios. Fish Sci 68:745-750

Yokoyama H, Tamak A, Harada K, Shimoda K, Koyama K, Ishihi Y (2005) Variability of diet-tissue isotopic fractionation in estuarine macrobenthos. Mar Ecol Prog Ser 296:115-128

Yuan XT, Yang HS, Wang LL, Zhou Y, Zhang T, Liu Y (2007) Effects of aestivation on the energy budget of sea cucumber Apostichopus japonicus (Selenka) (Echinaodermata: Holothuroidea). Acta Ecol Sin 27:3155-3161

Zar JH (2009) Biostatistical analysis, 5th edn. Prentice Hall, Upper Saddle River, NJ

Zhang BL, Sun DL, Wu YQ (1995) Preliminary analysis on the feeding habit of Apostichopus japonicus in the rocky coast waters off Lingshan Island. Mark Sci 3: 11-13

- Zheng ZM, Dong SL, Tian XL, Wang F, Gao QF, Bai PF (2009) Sediment-water fluxes of nutrients and dissolved organic carbon in extensive sea cucumber culture ponds. Clean Soil Air Water 37:218-224

Submitted: January 30, 2012; Accepted: April 26, 2012 Proofs received from author(s): June 15, 2012 